\title{
Use of food resources by the fish fauna of a small reservoir (rio Jordão, Brazil) before and shortly after its filling
}

\author{
Valdirene E. Loureiro-Crippa* and Norma S. Hahn**
}

\begin{abstract}
The construction of dams brings about changes in the course of a river, which directly or indirectly affect the fish fauna. Alterations in the food resources available to the fish favor some species and deter others. In addition to the implications originating from damming, Jordão Reservoir has a characteristically large number of endemic species that, because of the impacts they have undergone, run the risk of extinction. In this study, we investigate the feeding flexibility of the fishes faced with alterations in the food supply through the assessment of the diet and trophic organization of the fish fauna (before and after the damming). Diet was determined analyzing 1,861 stomach contents from 27 fish species. Eight of this species were not caught after the damming. Detrended Correspondence Analysis (DCA) discriminated seven trophic groups. Omnivorous, insectivorous and invertivorous species had more temporal alterations in their diets. These changes altered the composition (in abundance and biomass) of the trophic groups, mainly after the damming. The detritivorous and piscivorous species maintained their diets during all study period. Analyses showed that about $75 \%$ of the species quickly changed their diets according to alterations in food supply. This implies that food is not a limiting factor (at first) for the maintenance of fish fauna of this reservoir, at least for the species that persisted after the filling.
\end{abstract}

A construção de reservatórios causa mudanças no curso natural dos rios que afetam direta ou indiretamente a ictiofauna. Alterações na disponibilidade dos recursos alimentares favorecem algumas espécies e prejudicam outras. Além das implicações decorrentes do represamento, o reservatório de Jordão tem como característica um grande número de espécies de peixes endêmicas, que em função dos impactos causados por esse empreendimento, correm risco de extinção. Nesse estudo, nós investigamos como os peixes se comportaram frente às alterações no suprimento alimentar, através da dieta e organização trófica da ictiofauna (antes e após o represamento). Foram analisados 1861 conteúdos estomacais, pertencentes a 27 espécies. Oito dessas espécies não foram mais capturadas após o represamento. Uma análise de correspondência com remoção do efeito do arco (DCA) discriminou sete grupos tróficos. As espécies onívoras, insetívoras e invertívoras apresentaram alterações temporais acentuadas em suas dietas. Essas mudanças alteraram a composição (em abundância e biomassa) dos grupos tróficos, principalmente após o represamento. As espécies detritívoras e piscívoras mantiveram suas dietas durante todo o período de estudos. As análises mostraram que aproximadamente $75 \%$ das espécies mudaram rapidamente suas dietas de acordo com as alterações no suprimento alimentar. Este fato permite inferir que o alimento não é um fator limitante para a manutenção das espécies que permaneceram no reservatório de Jordão.

Key words: Fish diet, Feeding flexibility, Resources availability, Impacted environment.

\section{Introduction}

Reservoir filling and the physical, chemical and biological alterations associated with it have implications for the colonization of the new environment by fish fauna. This period is characterized by intensive environmental changes that follow the transformation of a terrestrial environment into an aquatic one (Agostinho et al., 1999). Studies about popula- tion structure and fish biology in Brazilian reservoirs have increased in the last decades (for reviews see Araújo-Lima et al., 1995; Hahn et al., 1997; Agostinho et al., 1999). However, these studies were developed only after damming, without a preliminary study of the autecology and interrelationships of the species in natural conditions.

Abiotic conditions in reservoirs (temperature, oxygen, $\mathrm{pH}$, presence of toxic substances, fluctuations in water level,

* Programa de Pós-graduação em Ecologia de Ambientes Aquáticos Continentais, Nupélia, Universidade Estadual de Maringá, Av. Colombo, 87020-900 Maringá, PR, Brazil. e-mail: crippaecrippa@yahoo.com.br

** Núcleo de Pesquisas em Limnologia, Ictiologia e Aqüicultura (Nupélia), Programa de Pós-graduação em Ecologia de Ambientes Aquáticos Continentais, Universidade Estadual de Maringá, Av. Colombo, 87020-900 Maringá, PR, Brazil. e-mail: hahnns@nupelia.uem.br 
among others) may be the most influential factors on either the absence or the presence of certain species (RodríguezRuiz, 1998). However, Paiva (1983) and Petts (1984) reported that the food resources are among the main factors for the maintenance of the requirements of fish in reservoirs. It is necessary to know their feeding habits in the river and dam phases in order to evaluate the impacts of the enterprise on the behavior of the fish fauna. The food supply is variable for the assemblages of fish that occupy the new environment causing rapid transformations particularly in the trophic organization (Hahn et al., 1998; Mérona et al., 2001; LuzAgostinho et al., 2006). Fishes may find in the new environment the food they are adapted to, or they may be able to change their diet according to the nature of the food available (Mérona et al., 2001). Therefore, based on the autecology of the species, we suppose that those with higher feeding flexibility will have better ability to successfully recolonize the environment impacted by damming.

Iguaçu Basin (where the Jordão Reservoir is located) has as its main feature a high degree of fish endemism due to its geographic isolation caused by the Iguaçu falls (Garavello et al., 1997). The maintenance of these species in the dammed environment is of central ecological importance because their local extinction will translate into global extinction.

Here, we show data on stomach contents analyses and trophic organization of the fish fauna of the Jordão Reservoir. The aim of this study was to investigate whether the food supply is a limit factor to the fish fauna, and to discuss whether the fishes, mainly the endemic species, would be able to adapt to the altered conditions in a lake-like reservoir.

\section{Material and Methods}

Study site. Jordão River is a tributary of the right bank of the Iguaçu River in its middle stretch. The river was dammed in April 1996, forming a small reservoir with a length of approximately $8 \mathrm{~km}$. The drainage basin covers an area of $4.780 \mathrm{~km}^{2}$ (Paiva, 1982). Its mouth in the Iguaçu River is located downstream of the dam of the Segredo Reservoir (Fig. 1).

Sampling and stomach analyses. Fish were collected at fixed sites in the pre-closure period (phase I- from September 95 to March 96) and post-closure period (phase II- from May 96 to January 97 and phase III- from February to November 97). Collections were performed using gill nets with different mesh sizes (between 24 and $140 \mathrm{~mm}$ opposite knots). Nets were left in the water for 24 hours, with inspections at 8:00, 17:00 and 22:00.

The 27 species analyzed have voucher specimens deposited at the Núcleo de Pesquisas em Limnologia, Ictiologia e Aqüicultura (Nupélia - Universidade Estadual de Maringá, Paraná State), under the numbers shown in the Table 1.

Stomach contents were analyzed by the volumetric method. For large items, the volume was obtained using graduated test tubes and for small items through the compression of the material with a glass slide over a counting chamber under a

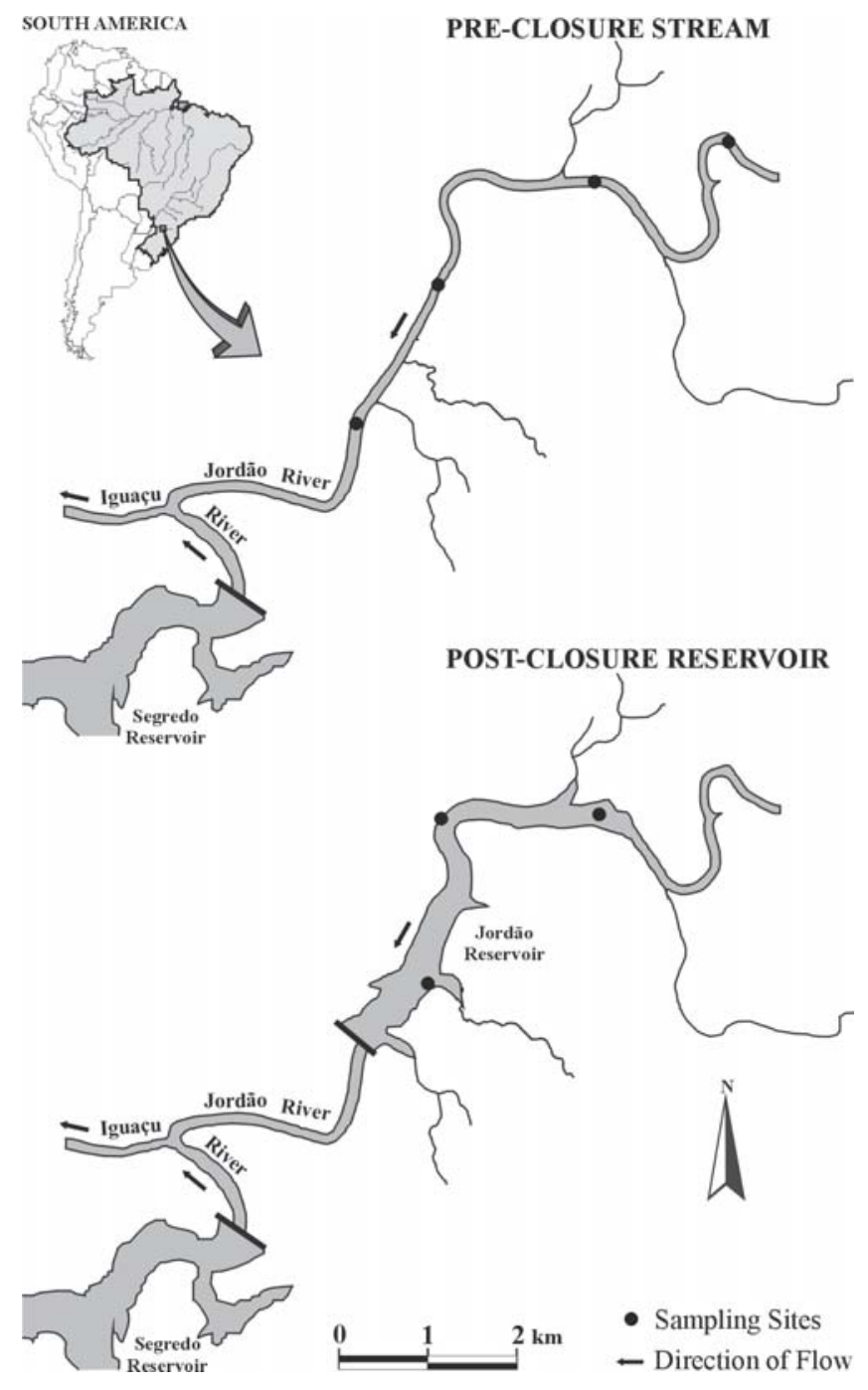

Fig. 1. Geographical location of Jordão River (Paraná State, Brazil) with indication of the study site.

stereomicroscope; items were grouped and the area occupied evaluated. The total area of food items was considered to be the total volume $(100 \%)$.

Data analysis. The patterns of feeding similarity between species were analyzed through detrended correspondence analysis (DCA; Hill \& Gauch, 1980; Gauch Jr., 1982) applied to the volume data of the food resources. The species were classified as: detritivorous (when there was a predominance of detritus in the diet), herbivorous (algae and/or higher plants), omnivorous (plants and animals in similar proportions), invertivorous (benthic invertebrates), insectivorous (terrestrial and aquatic insects), fish-crustacean feeders (fish and crabs) and piscivorous (fish).

In order to assess possible differences on relative abundance and biomass of the fish species for each trophic groups before and after damming catch per unit effort (CPUE) was used. For this analysis the piscivorous and fish-crustacean feeders were grouped. 


\section{Results}

Food resources in the diet. The contents of 1,861 stomachs were analyzed - 768 in phase I (belonging to 27 species), 411 in phase II ( 15 species) and 682 in phase III ( 17 species) (Table 1). In phase I, aquatic insects (Chironomidae and Ephemeroptera), fishes and plants were the most important food to $80 \%$ of the species. In the post-closure period, plants (fruits and seeds) were the most consumed food by 71.0 (phase II) and 81.0\% (phase III) of the fishes, followed by aquatic insects, 67.0 and $76.0 \%$ of the fishes for both phases. Among the species that consumed one type of food in more than $80 \%$ of their diets (specialist fishes) in phase I, were Gymnotus carapo, Hoplias malabaricus and Oligosarcus longirostris, which consumed fish, Hypostomus derbyi, detritus and Pariolius hollandi, which feed on crabs. In phase II, H. malabaricus, $O$. longirostris and $P$. hollandi consumed fish and Geophagus brasiliensis, insect larvae. In phase III, $H$. malabaricus, $O$. longirostris and Rhamdia voulezi ingested fish, and Astyanax altiparanae consumed plants.

Trophic group and temporal changes in the diet. Axes 1 of the DCAs were the most informative (eigenvalues $=0.74,0.85$ and 0.77 for phases I, II and III, respectively) (Fig. 2). The species with more specialized diets had extreme scores. The species that feed on detritus had the lowest scores and those that feed on fish and crabs had the highest scores.

In phase I, the detritivorous group was represented by $H$. derbyi, Corydoras paleatus and Apareiodon vittatus. The fish-crustacean feeders and piscivorous were composed by three species of Rhamdia, which consumed similar proportions of fish and crabs, O. longirostris, H. malabaricus and $G$. carapo, which almost exclusively fed on fish, and $P$. hollandi which basically consumed crabs. Species with intermediary scores (omnivorous, invertivorous, insectivorous) had more diversified diets (Figs. 2 a and d).

In phase II, the detritivorous group was represented only by $H$. derbyi and the omnivorous group by four species of Astyanax. Among the invertivorous species were, Astyanax sp. "c", C. iguassuensis, C. paleatus, G. brasiliensis and $P$. ortmanni that consumed mainly insect larvae. In the piscivorous group, Jenynsia sp. "a" was incorporated. Rhamdia sp. and $R$. voulezi were not registered (Figs. $2 \mathrm{~b}$ and e).

In phase III, the fish-crustacean feeders and piscivorous (R. voulezi, H. malabaricus and $O$. longirostris) were those more clearly segregated from a large group concentrated between the lowest and intermediary scores, composed of detritivorous, herbivorous and omnivorous species. The detritivorous group was enlarged by the inclusion of $G$. brasiliensis. Herbivorous group, was composed of species of the genus Astyanax (Astyanax sp. "f" and A. altiparanae). Species such as Jenynsia sp. "a”, C. paleatus, R. branneri and Astyanax sp. "b" (Figs. 2 c and f), which had been classified into diverse trophic groups in the previous phases, were incorporated into the insectivorous group.

Temporal variation in the composition of the fish fauna. The variations in the catches of the different species show that

Table 1. Food resources used by the fish fauna of the Jordão River/Reservoir in phases I, II and III. The data represent the percentage in volume. Ab. = abbreviations, $*=$ endemic species, $-=$ absence of specimens. Numbers in boldface indicate values $>50 \%$.

\begin{tabular}{|c|c|c|c|c|c|c|c|c|c|c|c|c|c|c|c|c|c|c|c|c|c|c|c|c|c|c|c|c|c|c|}
\hline \multirow{3}{*}{ Species } & \multirow{3}{*}{$\begin{array}{c}\text { Voucher } \\
\text { specimens }\end{array}$} & \multirow{3}{*}{\multicolumn{2}{|c|}{$\mathrm{Ab}}}$. & \multirow{2}{*}{\multicolumn{2}{|c|}{$\mathrm{N}$}} & \multirow{3}{*}{$\begin{array}{c}\mathrm{SL} \\
(\mathrm{mm})\end{array}$} & \multicolumn{24}{|c|}{ Food resources } \\
\hline & & & & & & & \multicolumn{3}{|c|}{ Fish } & \multicolumn{3}{|c|}{ Crabs } & \multicolumn{3}{|c|}{$\begin{array}{c}\text { Aquatic } \\
\text { invertebrates }\end{array}$} & \multicolumn{3}{|c|}{ Terrestrial insects } & \multicolumn{3}{|c|}{ Aquatic insects } & \multicolumn{3}{|c|}{ Algae } & \multicolumn{3}{|c|}{ Plants } & \multicolumn{3}{|c|}{ Detritus } \\
\hline & & & & II & III & & $\mathrm{I}$ & III & III & 1 & III & III & $\mathrm{I}$ & III & III & 1 & II & III & 1 & II & III & $\mathrm{I}$ & III & IIII & 1 & II & III & 1 & III & IIII \\
\hline${ }^{*}$ Appareiodon vittatus & NUP1584 (13) & A.vit & 27 & - & - & $77-105$ & 0.3 & - & - & & - & - & 0.7 & - & - & & - & - & 15.8 & - & - & 33.2 & - & - & 21.1 & - & - & 28.9 & - & - \\
\hline Astyanax altiparanae & NUP1314 (4) & A.alt & 11 & 3 & 2 & $57-103$ & 0.8 & & & & & & & & & 39.9 & 51.1 & 11.1 & & 8.9 & & & & & 56.9 & 40.0 & 88.9 & 2.4 & & \\
\hline * Astyanax sp. & (3) & Asty & 17 & - & 8 & $55-107$ & 0.1 & - & 0.2 & & - & 3.1 & 0.3 & - & 0.1 & 58.3 & - & 20.9 & 5.0 & - & 0.2 & & - & 6.3 & 35.3 & - & 31.4 & 1.0 & - & 37.8 \\
\hline *Astyanar sp. b & NUP2432 (6) & Ast.b 2 & 216 & 108 & 165 & $15-115$ & 4.1 & & 0.1 & 0.2 & & & 0.4 & 3.7 & 13.7 & 9.9 & 25.4 & 25.4 & 28.5 & 35.5 & 24.9 & 12.8 & 3.7 & 6.0 & 43.9 & 31.3 & 23.5 & 0.2 & 0.4 & 6.4 \\
\hline *Astyanax sp. c & $\begin{array}{l}\text { NUP2294 } \\
\text { (207) }\end{array}$ & Ast.c & 27 & 77 & 161 & $50-94$ & & 0.1 & 1.2 & & & & 0.1 & 7.1 & 7.4 & 4.3 & 12.6 & 7.7 & 27.7 & 44.1 & 16.3 & 1.8 & 11.0 & 17.1 & 58.0 & 6.7 & 18.3 & 8.1 & 18.4 & 32.0 \\
\hline *Astyanax sp. e & NUP1577 (16) & Ast.e & 42 & 90 & 70 & $52-119$ & 0.1 & & & 0.9 & & & 0.1 & 3.4 & 1.8 & 40.2 & 47.2 & 34.4 & 45.2 & 26.3 & 11.0 & 0.2 & - & 0.3 & 13.0 & 22.9 & 37.9 & 0.3 & 0.2 & 14.6 \\
\hline *Astyanax sp. f & NUP1579 (37) & Ast.f & 33 & 4 & 17 & $57-162$ & & & 0.1 & & & 0.3 & 0.8 & 0.2 & & 52.4 & 77.2 & 21.0 & 4.3 & 10.0 & 16.9 & & 9.3 & 0.4 & 42.5 & 3.3 & 60.0 & & & 1.3 \\
\hline * Bryconamericus sp. & NUP2400 (73) & Bryco & 6 & - & - & $54-60$ & 40.0 & - & - & & - & - & & - & - & & - & - & 20.0 & - & - & & - & - & 37.0 & - & - & 3.0 & - & - \\
\hline Corydoras paleatus & NUP1608 (22) & C.pal & 5 & 1 & 26 & $42-59$ & & & & & & & 26.1 & 23.3 & 39.5 & & & & 16.4 & 76.7 & 50.1 & & & 0.7 & & & 3.2 & 57.5 & & 6.5 \\
\hline $\begin{array}{l}\text { *Crenicichla } \\
\text { iguassuensis }\end{array}$ & NUP2429 (10) & C.igu & 12 & 6 & - & $80-158$ & 43.6 & & - & 6.2 & & - & 7.3 & 13.9 & - & & & - & 19.4 & 76.7 & - & 0.6 & & - & 16.9 & 5.8 & - & 6.0 & 3.6 & - \\
\hline Geophagus brasiliensis & NUP2431 (22) & G.bra & 44 & 2 & 3 & $64-166$ & 8.4 & & & & & & 21.7 & & 0.1 & 2.6 & & & 26.7 & 99.5 & 0.2 & 2.2 & & & 8.5 & 0.5 & 36.3 & 29.9 & & 63.4 \\
\hline * Glanidium ribeiroi & NUP1606 (2) & G.rib & 55 & - & 5 & $62-199$ & 0.2 & - & 1.2 & 12.3 & - & & 0.8 & - & 21.0 & 33.2 & - & 40.0 & 51.5 & - & 25.4 & 0.1 & - & 2.5 & 1.8 & - & 9.9 & & - & \\
\hline Gymnotus carapo & NUP1588 (15) & G.car & 4 & - & - & $\begin{array}{l}250- \\
312\end{array}$ & 84.5 & - & - & & - & - & & - & - & & - & - & 15.5 & - & - & & - & - & & - & - & & - & - \\
\hline $\begin{array}{l}\text { Hoplias aff. } \\
\text { malabaricus }\end{array}$ & NUP2433 (6) & H.mal & 14 & 3 & 26 & $65-375$ & 99.3 & 99.9 & 99.5 & & & & & & & 0.3 & & & & & & & & & 0.4 & 0.1 & 0.5 & & & - \\
\hline *Hypostomus derbyi & NUP1607 (2) & H.der & 16 & 4 & 6 & $\begin{array}{l}160- \\
246\end{array}$ & & 0.1 & & & & & 3.4 & 0.5 & 15.0 & 0.2 & & & 6.6 & 4.1 & 10.9 & 1.6 & 10.0 & 11.9 & 3.6 & 10.1 & 8.1 & 84.6 & 75.2 & 54.1 \\
\hline *Jenynsia sp. a & NUP2373 (2) & Jeny.a & 24 & 12 & 21 & $24-59$ & 11.5 & 68.8 & 22.7 & & & & 0.6 & 0.2 & 1.8 & 4.4 & & & 59.7 & 25.6 & 53.4 & 21.6 & 1.2 & 10.8 & & 4.2 & 6.6 & 2.2 & & 4.7 \\
\hline * Jenynsia sp. b & NUP2375 (2) & Jeny.b & 16 & - & - & $37-68$ & 6.5 & - & - & & - & - & & - & - & 3.4 & - & - & 65.6 & - & - & 6.9 & - & - & 17.6 & - & - & & - & - \\
\hline $\begin{array}{l}\text { * Oligosarcus } \\
\text { longirostris }\end{array}$ & NUP1585 (10) & O.lon & 36 & 44 & 95 & $24-253$ & 95.4 & 97.1 & 88.9 & & & & & & 0.1 & & 1.3 & 5.7 & 4.4 & 1.1 & 3.7 & 0.1 & & & & 0.5 & 1.5 & 0.1 & & 0.1 \\
\hline * Pariolius hollandi & NUP1593 (6) & P.holl & 4 & 2 & - & $85-235$ & 3.9 & 82.6 & - & 95.3 & 17.4 & - & & & - & 0.8 & & - & & & - & & & - & & & - & & & - \\
\hline * Pimelodus ortmanni & NUP1595 (20) & P.ort & 27 & 19 & 41 & $24-285$ & 11.4 & 2.3 & 5.3 & & & & 21.8 & 4.6 & 20.6 & 14.6 & 0.2 & 0.2 & 29.6 & 71.9 & 13.0 & 5.3 & 0.4 & & 5.8 & 6.4 & 42.5 & 11.5 & 14.2 & 18.4 \\
\hline *Pimelodus sp. & NUP1682 (10) & Pime & 23 & - & - & $84-142$ & 1.6 & - & - & & - & - & 6.6 & - & - & 6.1 & - & - & 65.9 & - & - & 1.2 & - & - & 18.6 & - & - & & - & - \\
\hline $\begin{array}{l}\text { *Psalidodon } \\
\text { gymnodontus }\end{array}$ & NUP1583 (26) & P.gym & 7 & - & - & $55-109$ & & - & - & & - & - & & - & - & 64.3 & - & - & 15.3 & - & - & & - & - & 20.1 & - & - & 0.3 & - & - \\
\hline *Psalidodon sp. & NUP1582 (15) & Psal & 5 & - & 10 & $54-162$ & & - & & & - & & & - & 0.6 & 60.2 & - & 62.7 & 0.8 & - & 16.5 & & - & 1.3 & 39.0 & - & 16.6 & & - & 2.3 \\
\hline * Rhamdia branneri & $\begin{array}{l}\text { NUP2428 (2) } \\
\text { NUP1587 (15) }\end{array}$ & R.bra & 51 & 36 & 23 & $66-350$ & 33.3 & 32.8 & 12.1 & 49.6 & 38.6 & 22.2 & & 0.5 & 0.6 & 14.3 & 10.6 & 34.0 & 2.3 & 15.7 & 23.2 & 0.1 & & & 0.4 & 1.8 & 6.3 & & & 1.6 \\
\hline *Rhamdia sp. & $\begin{array}{l}\text { NUP1527 (1) } \\
\text { NUP1594 (6) }\end{array}$ & Rham & 5 & - & - & $\begin{array}{l}195- \\
270\end{array}$ & 48.4 & - & - & 51.0 & - & - & & - & - & & - & - & & - & - & & - & - & 0.6 & - & - & & - & - \\
\hline * Rhamdia voulezi & NUP2426(11) & R.vou & 34 & - & 3 & $84-333$ & 40.8 & - & 83.1 & 51.6 & - & & 0.3 & - & & 0.4 & - & & 3.6 & - & 14.4 & & - & & 2.5 & - & 2.40 & 0.8 & - & 0.1 \\
\hline *Trichomycterus sp. & $\begin{array}{l}\text { absence } \\
\text { voucher }\end{array}$ & Trich & 7 & - & - & $35-120$ & 30.2 & - & - & 3.7 & - & - & 0.7 & - & - & 23.9 & - & - & 37.8 & - & - & 1.5 & - & - & 0.7 & - & - & 1.5 & - & - \\
\hline
\end{tabular}




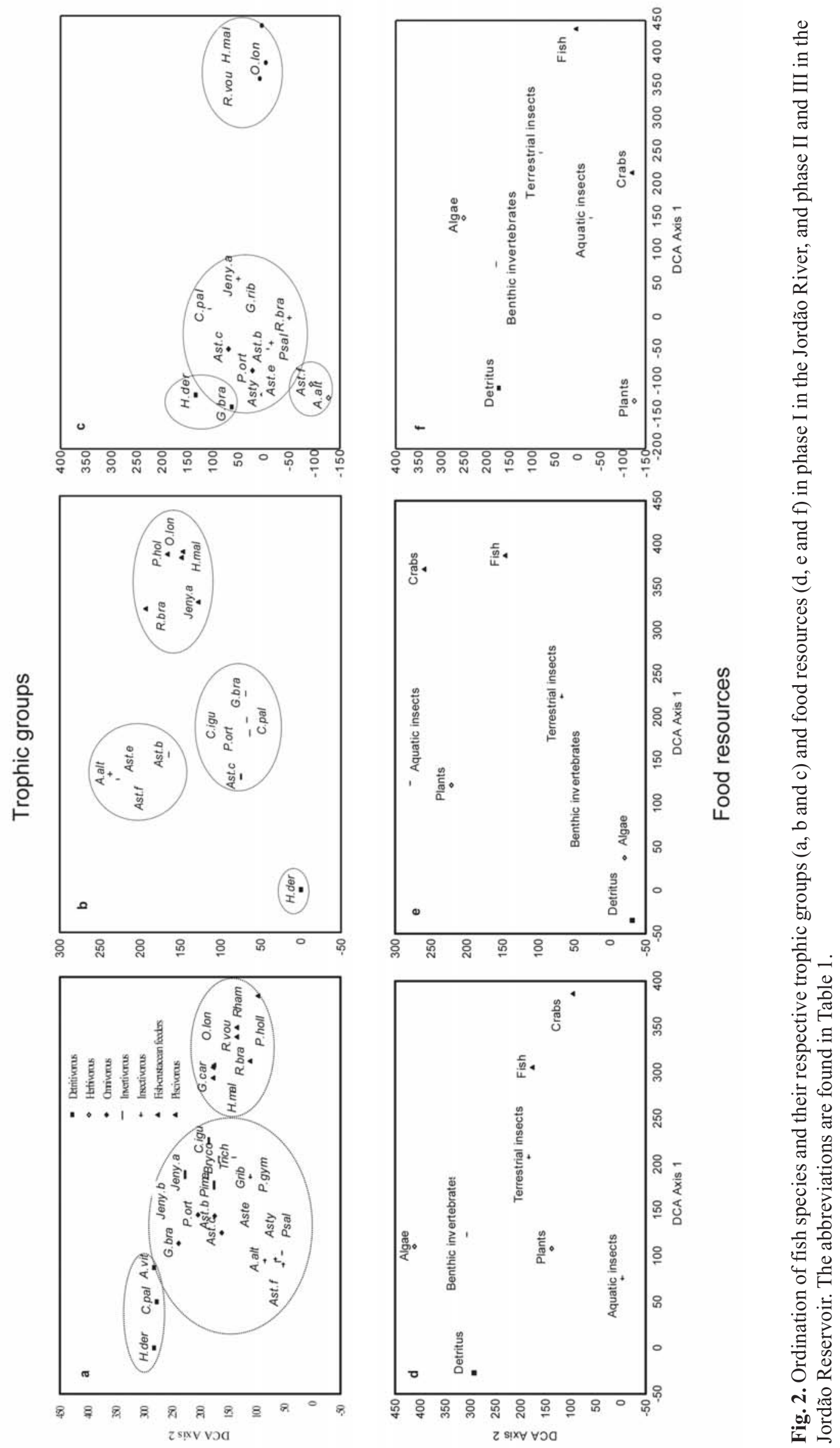



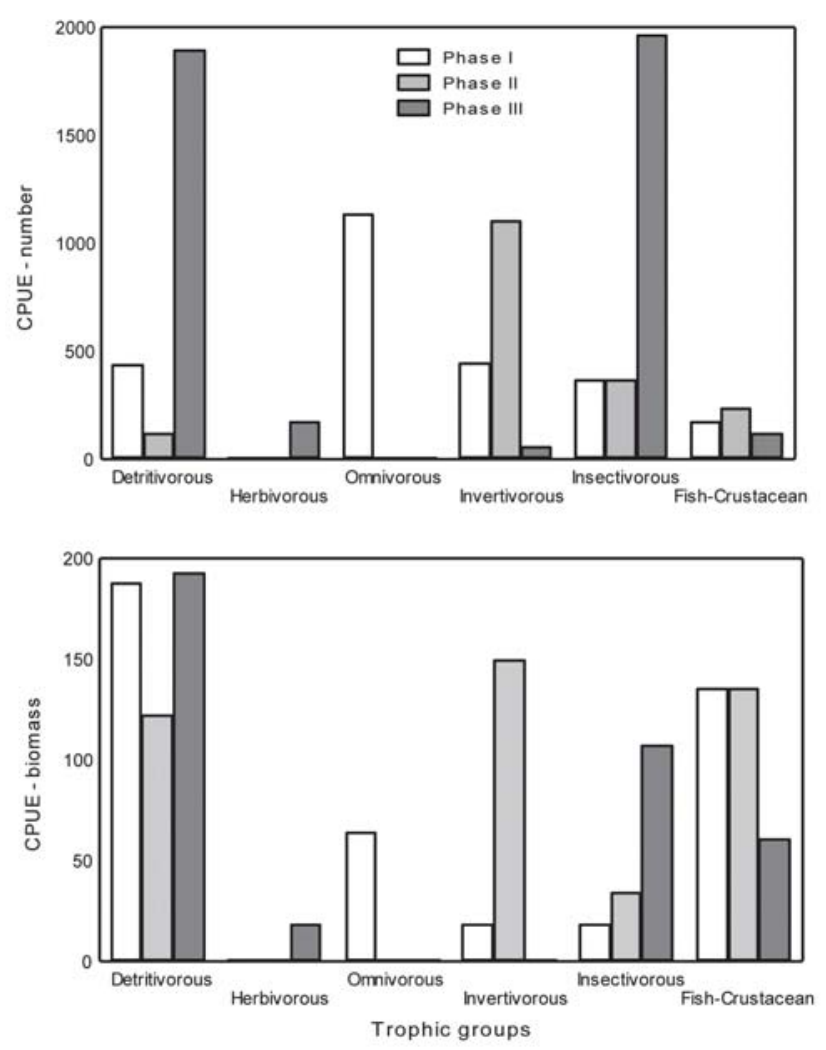

Fig. 3. Capture per unit of effort (CPUE), in abundance (a) and biomass (b) from different trophic groups.

the detritivorous, invertivorous, insectivorous and fish-crustacean feeders groups occurred during the whole period, with variations in species composition (Fig. 3).

In phase I, the predominant group in abundance was the omnivorous. In phase II, the invertivorous group prevailed and in phase III, the detritivorous and insectivorous were the main groups (Fig. 3a).

In phase I, the greatest contribution in biomass was attributed to the detritivorous group and the fish-crustacean feeders stood out in second position. In phase II, together with these two groups, the invertivorous were expressive. In phase III, the detritivorous group stood out again, and the insectivorous group stood out in the first time during the period of studies (Fig. 3b).

\section{Discussion}

Of the 27 species initially captured, eight (A. vittatus, Bryconamericus sp., G. carapo, Jenynsia sp. "b", Pimelodus sp., P. gymnodontus, Rhamdia sp. and Trichomycterus sp.) were not caught after the damming. The absence of these species in the collections after the damming does not allow conclude that they have disappeared from the environment. However, it is possible to infer that these species have had difficulties in immediately establishing themselves in the new environment.

According Fernando \& Holèík (1991) not all the species inhabiting the basin before the construction of the dam colonize the reservoir. The structure of the fish fauna in the first years of the damming, considered to be decisive in the pro- cess of subsequent colonization, seems to depend on the presence of elements of groups pre-adapted to lacustrine conditions and with high plasticity in reproductive and feeding strategies (Fernando \& Holèík, 1991; Rodriguez-Ruiz, 1998).

In recently formed reservoirs, many species change their food habits at least temporarily (Ferreira et al., 2002; Albrecht \& Caramaschi, 2003; Balassa et al., 2004) with the exception of specialist species (Mérona et al. 2001; Abujanra \& Agostinho, 2002) and those whose preferential food resources either increase (Cassemiro et al., 2003) or remain constant.

Stomach contents analyses of the fishes from Jordão Reservoir showed that the fish fauna is dominated by generalist/ opportunist species (almost $75 \%$ in number of species). The high consumption of terrestrial plants by the fishes after the damming occurred when there was an enhanced availability of this resource as immediate food. Another resource widely utilized after the damming was benthic organisms (including insect larvae), probably due to quick filling of the reservoir (16 days), making these organisms available in the column of water. Omnivorous, invertivorous and insectivorous fishes sometime changed temporally their diets. Specialist feeders were $H$. malabaricus and $O$. longirostris that maintained their habit (piscivorous) during the whole period and $H$. derbyi that exploited mainly detritus. Piscivorous species were supported by proliferation of small endemic forage species, especially tetragonopterins. The large food supply in the reservoir, allied to the opportunism of these prey will certainly allow the maintenance and/or explosion of these species in the dammed environment. This pattern is common in Neotropical reservoirs in the first stages of colonization (Agostinho et al., 1999; Luz-Agostinho et al., 2006).

Structural alterations in the trophic groups depending on the food resources exploited by fishes before and after the impoundment. Variations considered marked were those that involved sudden changes, for example, from insectivorous to herbivorous feeding habit, observed for $A$. altiparanae and Astyanax sp. "f"; and from invertivorous to piscivorous as in Jenynsia sp. "a". It is opportune to consider that to this last species, there is a possibility that the item (fish) found in the stomachs be their own larvae, because they have parental care and protect the offspring inside the mouth.

Species of the Astyanax, very abundant in the Jordão Reservoir, are highly flexible in their diets and some of them have been registered in the literature in different trophic groups. In our study, these fish also made up part of various groups and were responsible for the appearance of the herbivorous group in the reservoir exactly when it reached its highest levels of filling (phase III), flooding the terrestrial vegetation. The enlargement of the detritivorous group in phase III should have had the incorporation of $G$. brasiliensis that started to exploit this resource, probably in search of usual food items (benthic invertebrates).

The variations in relative abundance and biomass of the species, for each trophic group, were strongly influenced by the marked feeding flexibility of the fishes, since the fish positioned themselves temporally in distinct groups. According Agostinho et al. (1997), changes in the CPUE values ac- 
curately reflect the temporal and spatial variations in the abundance of fish in the environment.

The more striking increases in the different trophic groups, mainly in relative abundance, occurred due to the large catches of species of Astyanax. Since these species altered their diets, they contributed to the relevance of the groups they took part.

The detritivorous group, one with highest biomass, represented almost exclusively by $H$. derbyi, is due to its previous abundance in the river, average size and body covered by plates. It should be noticed that these variations are not due to the size of the specimens, since only small variations in size between individuals from different collections were verified. In phase III, however, the increase as much in relative abundance as in biomass of this group was due to G. brasiliensis (medium sized) that consumed large proportion of detritus. The relative abundance values were inexpressive for the fish-crustaceans feeders. However, in the Itaipu Reservoir, it was verified a very stable participation of piscivorous fish in the catches, in either relative abundance, number of species and biomass (Hahn et al., 1998). In our study, the species with the highest biomass contribution inside this group were $R$. branneri and $H$. malabaricus. In phase III, when an increase in these species was expected due to the wide availability of foraging species that possibly induce a large dispersion of predators into the environment in search of prey, the opposite was verified. This decline in the CPUE values of the fish-crustacean feeders can be interpreted by the absence of $R$. branneri, which changed to the insectivorous group. For the invertivorous group the increase in phase II occurred because $P$. ortmanni (large sized) and other species (medium and small sized) had a diet based on benthic organisms.

The results of this study reveal high opportunism and feeding flexibility of the fish species studied, including most of the endemic species. Nevertheless, it is valid to emphasize that any conclusion about the negative impacts that could have occurred to the fish fauna with the formation of the dam are speculations. Probably, in this environment the food is not a limiting factor for population maintenance.

\section{Acknowledgements}

We express our appreciation to Nupélia (Núcleo de Pesquisas em Limnologia, Ictiologia e Aqüicultura), to Copel and to PEA (Programa de Pós-graduação em Ecologia de Ambientes Aquáticos Continentais) for their financial support and infrastructure; Miguel Petrere Júnior and Carolina Viviana Minte-Vera for valuable suggestions.

\section{Literature Cited}

Abujanra, F. \& Agostinho, A. A. 2002. Dieta de Hypophthalmus edentatus (Spix, 1829), (Siluriformes, Hypophthalmidae) e variações de seu estoque no reservatório de Itaipu. Acta Scientiarum, 24: 401-410.

Agostinho, A. A., Hahn, N. S., Gomes, L. C. \& Bini L. M. 1997. Estrutura trófica. Pp. 229-248. In: Vazzoler, A. E. A. M., Agostinho, A. A. \& Hahn, N.S. (Eds.). A planície de inundação do alto rio
Paraná: aspectos físicos, biológicos e sócio-econômicos. EDUEM, Maringá, 460p.

Agostinho, A. A., Miranda, L. E., Bini, L. M., Gomes, L. C., Thomaz, S. M. \& Suzuki, H. I. 1999. Patterns of colonization in neotropical reservoirs, and prognoses on aging. Pp. 227-266. In: Tundisi, J. G. \& Straškraba, M. (Eds.). Theoretical reservoir ecology and its applications. International Institute of Ecology, São Carlos, 585p.

Albrecht, M. P. \& Caramaschi, E. P. 2003. Feeding ecology of Leporinus friderici (Teleostei; Anostomidae) in the upper Tocantins River, Central Brazil, before and after installation of a hydroelectric plant. Studies on Neotropical Fauna and Environment, 38: 33-40.

Araújo-Lima, C. A. R. M., Agostinho, A. A. \& Fabré, N. N. 1995. Trophic aspects of fish communities in Brazilian rivers and reservoirs. Pp. 105-136. In: Tundisi, J. G., Bicudo, C. E. M. \& Matsumura-Tundisi, T. (Eds.). Limnology in Brazil. ABC/SBL, Rio de Janeiro, 376p.

Balassa, G. C., Fugi, R., Hahn, N. S. \& Galina, A. B. 2004. Dieta de espécies de Anostomidae (Teleostei, Characiformes) na área de influência do reservatório de Manso, Mato Grosso, Brasil. Iheringia, Série Zoologia, 94: 77-82.

Cassemiro, F. A. S., Hahn, N. S. \& Rangel, T. F. L. V. B. 2003. Diet and trophic ecomorphology of the silverside, Odontesthes bonariensis, of the Salto Caxias Reservoir, Rio Iguaçu, Paraná, Brazil. Neotropical Ichthyology, 1: 127-131.

Fernando, C. H. \& Holèík, J. 1991. Fish in reservoirs. Internationale Revue der Gesamten Hydrobiologie, 76: 149-167.

Ferreira, A., Hahn, N. S. \& Delariva, R. L. 2002. Ecologia alimentar de Piabina argentea (Teleostei, Tetragonopterinae) nas fases de pré e pós-represamento do rio Corumbá, GO. Acta Limnologica Brasiliensia, 14: 43-52.

Garavello, J. C., Pavanelli, C. S. \& Suzuki, H. I. 1997. Caracterização da ictiofauna do rio Iguaçu. Pp. 61-84. In: Agostinho, A. A. \& Gomes, L. C. (Eds.). Reservatório de Segredo: bases ecológicas para o manejo. EDUEM, Maringá, 387p.

Gauch Jr., H. G. 1982. Multivariate analysis in community ecology. Cambridge, Cambridge University Press, 298p.

Hahn, N. S., Fugi, R., Almeida, V. L. L, Russo, M. R. \& Loureiro, V. E. 1997. Dieta e atividade alimentar de peixes do reservatório de Segredo. Pp. 141-162. In: Agostinho, A. A. \& Gomes, L. C. (Eds.). Reservatório de Segredo: bases ecológicas para o manejo. EDUEM, Maringá, 387p.

Hahn, N. S., Agostinho, A. A., Gomes, L. C. \& Bini, L. M. 1998. Estrutura trófica da ictiofauna do reservatório de Itaipu (Paraná-Brasil) nos primeiros anos de sua formação. Interciência, 23: 299-305.

Hill, M. O. \& Gauch Jr., H. G. 1980. Detrended correspondence analysis: an improved ordination technique. Vegetatio, 42: 47-58.

Luz-Agostinho, K. D. G., Bini, L. M., Fugi, R., Agostinho, A. A. \& Júlio Júnior, H. F. 2006. Food spectrum and trophic structure of the ichthyofauna of Corumbá reservoir, Paraná River Basin, Brazil. Neotropical Ichthyology, 41 (1): 61-68.

Mérona, B., Santos, G. M. \& Almeida, R. G. 2001. Short term effects of Tucuruí (Amazônia, Brazil) on the trophic organization of fish communities. Environmental Biology of Fishes, 60: 375-392.

Paiva, M. P. 1982. Grandes represas do Brasil. Editerra, Brasília, 292p.

Paiva, M. P. 1983. Peixes e pesca de águas interiores do Brasil. Editerra, Brasília, 158p.

Petts, G. E. 1984. Impounded rivers: Perspectives for ecological management. Environmental Monographs and Symposia. John Wiley \& Sons, Chichester, $326 \mathrm{p}$.

Rodríguez-Ruiz, A. 1998. Fish species composition before and after construction of a reservoir on the Guadalete River (SW Spain). Archiv fuer Hydrobiologie 142: 353-369.

Received June 2006 Accepted August 2006 